\title{
Effect of preceding crops on the winter cereal productivity and diseases incidence
}

\author{
Regina SKUODIENE ${ }^{1}$, Rita NEKROŠIENE ${ }^{2}$
}

Received August 12, 2008; accepted April 8, 2009.

Delo je prispelo 12. avgusta 2008, sprejeto 8. aprila 2009.

\section{ABSTRACT}

Experiments were carried out in the Vèžaičiai Branch of the Lithuanian Institute of Agriculture (West Lithuania region) in 2002-2005. The aim of this research was to estimate the ecological significance of perennial legumes used as green manure for the biological properties of triticale and rye and for diseases resistance. Residues of the perennial grasses tested and ploughed-in aftermath contributed different contents of nitrogen to the soil. The highest content of nitrogen was contributed to the soil with red clover residues and aftermath. Residues of white clover and aftermath ploughed in as green manure determined more favourable soil properties. This had a positive effect on the formation of biological parameters of cereals grown after white clover, which made it possible without mineral and organic fertilisers to produce on average $3.88 \mathrm{tha}^{-1}$ of triticale grain and $3.82 \mathrm{t} \mathrm{ha}^{-1}$ of rye grain, or by 1.09 and $0.28 \mathrm{t} \mathrm{ha}^{-1}$ more compared with their growing after red clover managed in the same way as white clover. Different growing conditions of winter cereals, i.e. different preceding crops, had a significant effect on the occurrence of scald and septoriosis.

Key words: preceding crops, winter cereal, productivity, yield forming indicators, diseases

\section{IZVLE Č E K}

\section{VPLIV PREDHODNIH POSEVKOV NA PRIDELEK TER POJAVNOST BOLEZNI PRI OZIMNIH ŽITIH}

Poskusi so bili opravljeni v Véžaičiai Branch na Lithuanian Institute of Agriculture v obdobju od leta 2002 do 2005. Namen raziskave je bil oceniti ekološki pomen trajnih metuljnic, uporabljenih za zeleno gnojenje, na odpornost proti boleznim ter na biološke lastnosti tritikale in rži. Zaorani ostanki zelenih delov preizkušanih metuljnic so imeli različne vplive na vsebnost dušika $v$ tleh. $K$ najvišji vsebnosti dušika so prispevali ostanki rdeče detelje, zaorani ostanki bele detelje pa so imeli ugodnejše učinke na lastnosti tal. Izboljšane talne lastnosti so pozitivno vplivale na parametre rasti, ki so omogočili pridelek 3,88 $\mathrm{t} \mathrm{ha}^{-1}$ zrnja tritikale in 3,82 $\mathrm{t} \mathrm{ha}^{-1}$ zrnja rži brez uporabe mineralnih ali drugih organskih gnojil. Ko je bil predhodni posevek rdeča detelja, je bil pridelek tritikale manjši za $1,09 \mathrm{t} \mathrm{ha}^{-1}$, pridelek rži pa za $0,28 \mathrm{t} \mathrm{ha}^{-1}$ manjši $\mathrm{v}$ primerjavi s pridelkom po zelenem gnojenju $\mathrm{z}$ belo deteljo. Različni predhodni posevki so imeli pomemben vpliv na pojavnost ožiga in listne pegavosti.

Ključne besede: predhodni posevki, ozimna žita, pridelek, bolezni

\section{INTRODUCTION}

Winter rye (Secale cereale L.) is a very important bread cereal. Rye grain dry matter contains $9-19 \%$ of protein, $49-66 \%$ of starch, $1.6-1.9 \%$ of fat, $2.0-2.5$ $\%$ of fibre, various trace elements and vitamins. Winter rye can tolerate acidic soil, is less demanding in terms of nutrient content and can better utilise soil moisture in spring.
Winter triticale ( $\times$ Triticosecale Wittm.), compared with wheat performs better on poorer or even acidic soils (Magyla et al., 2001). In good conditions the grain yield can be as high as $8-10 \mathrm{tha}^{-1}$ and can exhibit valuable biochemical, physiological and agronomical characteristics. Triticale grain contains $12-19 \%$ of protein with an appropriate composition of amino acids.

1 Lithuanian Institute of Agriculture, Vèžaičiai Branch, Gargždu 29, LT 96216 Klaipèda distr., Lithuania, e-mail: rskuod@vezaiciai.Izi.It, Ph.D.

2 Botanical Garden of Klaipeda University, Kretingos 92, LT 92327 Klaipeda, Lithuania, e-mail: rita_nekrosiene@mail.ru, Ph.D. 
Winter triticale and rye are a promising alternative feed crop in Estonia, Latvia and Poland (Alaru et al., 2003). Winter cereal should be an acceptable alternative crop possessing considerable potential as a source of energy and protein in Lithuania too. There were sown about 56 thousand ha by this crop in our country in 2002 .

The productivity of winter cereals depends on soil properties, meteorological factors, fertilisation, and especially humus content in the soil. The residues and ploughed in green material of perennial grasses, as preceding crops, have a positive effect on the formation of productivity elements of cereal crops not only in the first year but also in the second year, which determines the productivity of cereal link (Arlauskiene, 2000). The largest amount of organic matter is left in the soil with the residues of perennial grasses, less with annual grasses, winter cereals, maize, spring cereals, grain legumes and others (Arlauskienè, 2000; Janušienè, 1992; Magyla et al., 1997). In the crop rotations with perennial grasses with plant residues the soil receives much more $\mathrm{C}, \mathrm{N}$ and ashy elements $\mathrm{P}_{2} \mathrm{O}_{5}$ and $\mathrm{K}_{2} \mathrm{O}$ (Шпаков, 1999).

Winter cereals are annually heavily damaged by the diseases such as scald, leaf spots, various rusts, root rot diseases. Many authors indicate that the incidence of fungal diseases of winter cereals is determined by the weather conditions, imbalanced mineral fertilisation, crop species and variety, soil preparation, sowing time, preceding crop, weed infestation, abundance of pests, and luxuriance of the crop stand. More abundant mineral fertilisation of winter cereals in some cases slows down the spread of Septoria, but sometimes has virtually no effect. Some researchers' data suggest that more abundant fertilisation promotes the spread of Septoria (Bailey et al., 1996; Conway, 1996; Eyal, 1999; Gaurilčikienè et al., 1999; Hutcheon et al., 1996; Lisova et al., 1996). However, experimental results often vary considerably between years. It is maintained that preceding crops of winter cereals have quite a weighty effect on the occurrence of root rots, however, there is little experimental evidence on the effects of this factor on the spread of foliar diseases (Loiveke et al., 2003).

Research on the use of various herbaceous species for green manure in contemporary agriculture has gained new relevance. Cheap and high quality green manure is an important element in crop alternation in specialised cereal crop rotations. The use of green manure tends to reduce weed, disease and pest incidence, and less nutrients are leached from the plough layer into deeper soil layers (Romanovskaja et al., 2003).

The aim of this research was to determine effect of preceding crops (perennial legumes as green manure) on the productivity of winter cereals and occurrence of their diseases.

\section{MATERIAL AND METHODS}

\section{Experimental layout}

Two analogous experiments were set up in 2002 and 2003, each experiment lasted for three years. The field experiments were done following multi-factorial method. The experimental treatments were replicated four times and were arranged randomly. The soil of the experimental site is albi edohypogleyic luvisol, light loam on medium heavy loam.

\author{
A factor - preceding crops of winter cereals: \\ 1. Red clover - cut twice (R). \\ 2. Red clover $-1^{\text {st }}$ crop for forage, aftermath ploughed in \\ $(\mathrm{R}+\mathrm{A})$. \\ 3. White clover - cut twice (R). \\ 4. White clover -1 st crop for forage, aftermath ploughed in \\ $(\mathrm{R}+\mathrm{A})$. \\ 5. Timothy - cut twice $2(\mathrm{R})$. \\ B factor - cereals: \\ 1. Triticale. \\ 2. Rye.
}

The triticale variety 'Tevo' and rye variety 'Rūkai' were grown observing ecological cultivation recommendations. The cereals were grown after differently managed preceding crops: red clover 'Vyliai', white clover 'Sūduviai' and timothy 'Gintaras II'.
Plant green material was chopped and shallowly incorporated during phytocenosis flourishing period, and after two weeks deeply ploughed in $(25 \mathrm{~cm})$. In 2003 cereals were sown on September 8 and in 2004 on September 6. Seeking to determine the ecological value of different preceding crops no mineral fertilisers and plant protection products were used.

Soil samples were collected before trial establishment and after perennial grasses ploughing in from the $0-20 \mathrm{~cm}$ depth. Available $\mathrm{P}_{2} \mathrm{O}_{5}$ and $\mathrm{K}_{2} \mathrm{O}$ were determined by the A-L method, total nitrogen by Kjeldahl, organic carbon by a mineraliser 'Heraeus'.

Plant residue mass was determined by the Katchinski monolith washing method. We considered the following as plant residues: stubble, undecomposed plant parts present on the soil surface and roots situated at the $25 \mathrm{~cm}$ depth. The mass of all plant residues and overground mass were re-calculated into dry matter. Having determined the concentration of major nutrients we calculated the content of nutrients $\left(\mathrm{kg} \mathrm{ha}^{-1}\right)$ incorporated into the soil. The content of phosphorus in the green material of preceding crops, their plant residues and cereal grain and straw was determined by colorimetry and potassium by flame photometry methods. The share of nitrogen fixed from the atmosphere by legume bacteria in the 
plant mass was calculated by multiplying nitrogen content by the Chopkins - Piters coefficient 0.63 (Trepačev, 1979).

Grain samples for analyses were taken from each plot after pre-cleaning. One thousand grain weight was determined according to ISO 580-77. The data on 1000 grain weight and yield were adjusted to $15 \%$ moisture content.

\section{Diseases assessment}

Foliar disease assessments on rye and winter triticale were carried out in 2004-2005 in the third ten-day period of June at late milk maturity stage (BBCH 77-80). In each area under assessment 10 places were randomly chosen and three normally developed stems were taken per place. Three top green leaves were assessed per stem (Šurkus et al., 2002).

The following methods were used for the diagnostics of fungal diseases: visual, according to external symptoms and microscopy.

Disease incidence, i.e. per cent of disease-affected leaves (P) was calculated according to the formula:

$\mathrm{P}=\begin{aligned} & \mathrm{n} \\ & -\mathrm{N}\end{aligned} \quad \begin{aligned} & \mathrm{N} \\ & \mathrm{N}-\text { number of assessed leaves. }\end{aligned}$

The disease-affected leaf area was estimated in per cent according to the scale recommended by the European Plant Protection Organisation (EPPO). This scale is included in the EPPO Standards (1997) .

Table 1. Meteorological conditions of the vegetation period
Disease severity $(\mathrm{R})$ was calculated according to the formula, having added per cent of affected leaf area of each leaf and having divided the sum by the number of assessed leaves:
$\mathrm{R}=\underline{\sum(\mathrm{n} \cdot \mathrm{b})}$, where $\sum(\mathrm{n} \cdot \mathrm{b})-$ sum of product of the
number of leaves with the same percen of severity and value of severity, $\mathrm{N}$ - number of assessed leaves.

\section{Meteorological conditions}

In the spring of 2002 warm and dry weather prevailed. At the beginning of summer there was sufficient warmth and moisture for the development of perennial grasses, and in August with prevailing dry weather and declining moisture reserves, the conditions for grass growth were only satisfactory (Table 1). The drought lasted until the second tenday period of September. In the spring and summer of 2003, except for July, hydrothermal conditions were favourable for the development of perennial grasses. The autumn conditions were also conducive to the emergence, establishment and growth of cereals. During the spring-summer period of 2004 agrometeorological conditions for the development of cereals and perennial grasses were satisfactory. The autumn was warm and wet, which might have intensified biochemical processes in the soil and leaching of some part of released nitrogen. In 2005 the spring and beginning of summer were drier (rainfall only $80 \%$ ) compared with the long-term mean. Rainy second half of spring hindered cereal harvesting.

\begin{tabular}{|c|c|c|c|c|c|c|c|c|c|c|}
\hline \multirow{3}{*}{ Month } & \multicolumn{5}{|c|}{ Air temperature $\left({ }^{\circ} \mathrm{C}\right)$} & \multicolumn{5}{|c|}{ Rainfall (mm) } \\
\hline & \multicolumn{3}{|c|}{ decade } & \multirow[b]{2}{*}{$\begin{array}{c}\text { per } \\
\text { month }\end{array}$} & \multirow{2}{*}{$\begin{array}{c}+/- \text { of the } \\
\text { long-term } \\
\text { mean }\end{array}$} & \multicolumn{3}{|c|}{ decade } & \multirow[b]{2}{*}{$\begin{array}{c}\text { per } \\
\text { month }\end{array}$} & \multirow{2}{*}{$\begin{array}{c}+/- \text { of the } \\
\text { long-term } \\
\text { mean }\end{array}$} \\
\hline & I & II & III & & & I & II & III & & \\
\hline \multicolumn{11}{|c|}{ Year 2002} \\
\hline April & 3.1 & 8.8 & 9.5 & 7.1 & +1.5 & 0.4 & 3.8 & 9.9 & 14.1 & -29.9 \\
\hline May & 17.0 & 12.4 & 16.4 & 15.3 & +4.1 & 0.3 & 11.6 & 8.4 & 20.3 & -23.8 \\
\hline June & 16.5 & 16.3 & 14.5 & 15.8 & +1.0 & 1.0 & 41.2 & 21.3 & 63.5 & -0.3 \\
\hline July & 17.1 & 20.6 & 18.2 & 18.6 & +1.8 & 32.7 & 56.8 & 42.9 & 132.4 & +45.8 \\
\hline August & 20.3 & 20.8 & 18.8 & 20.0 & +3.6 & 0 & 0 & 0.3 & 0.3 & -88.7 \\
\hline \multicolumn{11}{|c|}{ Year 2003} \\
\hline April & 0.0 & 6.1 & 8.5 & 4.9 & -0.7 & 19.2 & 9.5 & 18.5 & 47.2 & +3.1 \\
\hline May & 9.5 & 10.9 & 14.3 & 11.6 & +0.4 & 14.9 & 23.5 & 4.1 & 42.5 & +1.6 \\
\hline June & 15.5 & 13.3 & 14.9 & 14.6 & -0.2 & 2.5 & 19.6 & 50.6 & 72.7 & +8.8 \\
\hline July & 17.0 & 19.7 & 21.4 & 19.4 & +2.6 & 22.8 & 13.5 & 11.6 & 47.9 & -38.0 \\
\hline August & 18.7 & 17.1 & 14.4 & 16.7 & +0.3 & 10.0 & 35.2 & 71.6 & 116.8 & +27.3 \\
\hline \multicolumn{11}{|c|}{ Year 2004} \\
\hline April & 5.1 & 8.2 & 8.4 & 7.2 & +1.6 & 6.4 & 5.7 & 3.7 & 15.8 & -27.8 \\
\hline May & 15.0 & 8.5 & 8.7 & 10.7 & -0.5 & 4.6 & 16.2 & 16.0 & 36.8 & -7.1 \\
\hline June & 13.7 & 12.5 & 14.1 & 13.4 & -1.3 & 3.5 & 41.7 & 23.7 & 68.9 & +4.9 \\
\hline July & 15.1 & 15.4 & 17.0 & 15.8 & -1.0 & 31.7 & 12.9 & 7.9 & 52.5 & -32.8 \\
\hline August & 20.5 & 17.9 & 16.0 & 18.1 & +1.7 & 4.2 & 30.3 & 29.9 & 64.4 & -24.7 \\
\hline \multicolumn{11}{|c|}{ Year 2005} \\
\hline April & 5.0 & 8.2 & 5.5 & 6.2 & +0.6 & 10.0 & 2.0 & 3.0 & 15.0 & -28.1 \\
\hline May & 8.6 & 8.9 & 15.8 & 11.1 & -0.1 & 5.0 & 27.0 & 6.0 & 37.0 & -6.8 \\
\hline June & 12.0 & 15.5 & 15.6 & 14.4 & -0.3 & 6.0 & 30.0 & 9.0 & 45.0 & -18.7 \\
\hline July & 18.6 & 19.8 & 17.4 & 18.6 & +1.8 & 36.0 & 98.0 & 59.0 & 193.0 & +105.8 \\
\hline August & 16.2 & 15.6 & 16.6 & 16.1 & -0.3 & 171.0 & 81.0 & 15.0 & 267.0 & +174.9 \\
\hline
\end{tabular}

The experimental data were processed by ANOVA and correlation-regression analysis methods (Tarakanovas et al., 2003).

The symbols used in the paper: $*$ and $* *$ significant at 95 and $99 \%$ probability level; $\mathrm{R}$ - ploughed in residues, $\mathrm{R}+\mathrm{A}-$ ploughed in residues and aftermath. 


\section{RESULTS AND DISCUSSION}

Amount of nutrients, soil agrochemical properties In the sowing year conditions were favourable for the growth of perennial grasses, however, legumes and grasses differed in phytomass and productivity coefficients. Overground phytomass of legumes was by $2.5-2.9$ times higher than underground, and that of timothy by 0.9 times lower, whereas biological productivity coefficients amounted to $0.32-0.40$ and 1.26 , respectively. A similar trend was identified also in the years of grass use. Underground phytomass of legumes significantly correlated with overground phytomass (white clover $\mathrm{r}=0.635^{* *}$ and red clover $\mathrm{r}=$ $0.582 *)$, that is with increasing overground phytomass, underground phytomass increased, too. Having ploughed in aftermath, legumes left in the soil $70-71 \%$ of the total phytomass in the form of roots and plant residues: red clover 8.8 , and white clover $5.8 \mathrm{t} \mathrm{ha}^{-1}$ dry matter.

Analyses of chemical composition of green manure showed that the highest concentrations of nitrogen, phosphorus and potassium were found in white clover overground phytomass, $(2.80,0.76$ ir $2.95 \%$ respectively). In the aboveground phytomass of red clover the contents of the above-mentioned biogenic elements were lower by $14,25,21 \%$, respectively. Plant overground part was richer in nutrients than underground part: nitrogen content by $1.4-1.6$, phosphorus by $2.2-4.0$ and potassium by $2.1-3.6$ times. The lowest nutrient concentration was identified in the residues of timothy $\left(0.74 \% \mathrm{~N}, 0.15 \% \quad \mathrm{P}_{2} \mathrm{O}_{5}\right.$, $0.57 \% \quad \mathrm{~K}_{2} \mathrm{O}$ respectively). The largest amount of all nutrients was contributed to the soil after ploughing in of red clover aftermath (Table 2).

Table 2. Amount of nutrients incorporated into the soil with plant residues of preceding crops and with aftermath

\begin{tabular}{|c|c|c|c|c|c|c|}
\hline \multirow{3}{*}{$\begin{array}{l}\text { Preceding crops of } \\
\text { winter cereals }\end{array}$} & \multirow{3}{*}{$\begin{array}{l}\text { DM of plant } \\
\text { residues and } \\
\text { green manure }\end{array}$} & \multicolumn{4}{|c|}{ Nutrients kg ha ${ }^{-1}$} & \multirow{3}{*}{$\mathrm{N}: \mathrm{P}_{2} \mathrm{O}_{5}: \mathrm{K}_{2} \mathrm{O}$} \\
\hline & & \multicolumn{2}{|c|}{$\mathrm{N}$} & \multirow{2}{*}{$\mathrm{P}_{2} \mathrm{O}_{5}$} & \multirow{2}{*}{$\mathrm{K}_{2} \mathrm{O}$} & \\
\hline & & total & fixed & & & \\
\hline 1. Red clover $(\mathrm{R})$ & 8.19 & 144.8 & 91.2 & 37.4 & 85.9 & $1: 0.3: 0.6$ \\
\hline 2. Red clover $(\mathrm{R}+\mathrm{A})$ & 10.1 & 185.8 & 117.0 & 50.1 & 138.0 & $1: 0.3: 0.7$ \\
\hline 3. White clover $(\mathrm{R})$ & 5.58 & 68.9 & 43.4 & 15.6 & 38.5 & $1: 0.2: 0.6$ \\
\hline 4. White clover $(\mathrm{R}+\mathrm{A})$ & 7.18 & 125.9 & 79.3 & 33.4 & 94.9 & $1: 0.3: 0.8$ \\
\hline 5. Timothy $(\mathrm{R})$ & 8.59 & 60.2 & - & 18.4 & 40.9 & $1: 0.3: 0.7$ \\
\hline
\end{tabular}

With incorporation of lower dry matter contents of green manure, which was determined by the yield of plant species and weather conditions, the soil received less nutrients than with plant residues. After red clover, with overground phytomass and residues the soil received $185.8 \mathrm{~kg} \mathrm{ha}^{-1}$ nitrogen, of which nitrogen fixed by legume bacteria from the atmosphere accounted for the larger $\left(117.0 \mathrm{~kg} \mathrm{ha}^{-1}\right)$ part. Here the content of nitrogen was by 1.5 times higher than after identically managed white clover.

The largest amounts of phosphorus and potassium, like those of nitrogen, were contributed to the soil with red clover overground phytomass and residues. With red and white clover aftermath incorporated (2.22 and $2.07 \mathrm{t} \mathrm{ha}^{-1}$ dry matter), the soil received more nutrients than with ploughed in root and plant residues of the above mentioned clovers: nitrogen by $1.3-1.8$, phosphorus by $1.3-2.1$ and potassium by $1.6-2.5$ times more. Although with lower mass the soil received less nutrients, the ratio $\mathrm{N}: \mathrm{P}_{2} \mathrm{O}_{5}: \mathrm{K}_{2} \mathrm{O}$ remained similar, i.e. $1 \mathrm{~kg}: 0.2-0.3 \mathrm{~kg}: 0.6-0.7 \mathrm{~kg}$.

The value and effect of preceding crops depend not only on the amount and chemical composition of phytomass but also on soil and climate conditions (Granstedt, 2000, Magyla et al., 2004). It was found that in sandy loam luvisol (East Lithuania) with red clover aftermath yield the soil received on average $94.9 \mathrm{~kg} \mathrm{ha}^{-1}$ of nitrogen, $8.64 \mathrm{~kg} \mathrm{ha}^{-1}$ of phosphorus and $88.3 \mathrm{~kg} \mathrm{ha}^{-1}$ of potassium (Romanovskaja et al., 2003). Under North Lithuania's conditions where sod calcareous heavy loam soils prevail the greatest amounts of nutrients are left in the soil after bastard lucerne and red clover, while the lowest contents are left after vetch and oats mixture.

Perennial grasses with different biological characteristics determined a diverse accumulation of total nitrogen, humus and available $\mathrm{P}_{2} \mathrm{O}_{5}$ and $\mathrm{K}_{2} \mathrm{O}$ in the soil (Table 3). Experimental evidence indicates that in the plough layer $(0-20 \mathrm{~cm}$ depth) after all preceding crops the content of total nitrogen was similar $(0.105-$ $0.120 \%$ ), however, compared with its content before the trial the content of total nitrogen after red clover was by $14-28 \%$ higher, after white clover by $31-33 \%$ higher. The highest increase in humus content $(0.25$ percentage units) occurred with ploughing in red clover aftermath, slightly less (0.21 percentage units) with variously managed white clover. The largest amount of available phosphorus in the plough layer was identified after red 
clover, whose aftermath was ploughed in, and that of available potassium after identically managed white clover.

Table 3. The effect of different legumes on soil agrochemical properties

\begin{tabular}{lcccccccc}
\hline \multicolumn{1}{c}{$\begin{array}{c}\text { Preceding crops } \\
\text { of winter cereals }\end{array}$} & \multicolumn{2}{c}{$\mathrm{N} \%$} & \multicolumn{2}{c}{ Humus $\%$} & \multicolumn{2}{c}{$\mathrm{P}_{2} \mathrm{O}_{5} \mathrm{mg} \mathrm{kg}^{-1}$} & \multicolumn{2}{c}{$\mathrm{K}_{2} \mathrm{O} \mathrm{mg} \mathrm{kg}^{-1}$} \\
\cline { 2 - 9 } & 1 & 2 & 1 & 2 & 1 & 2 & 1 & 2 \\
\hline 1. Red clover (R) & 0.105 & 0.120 & 1.56 & 1.66 & 179 & 147 & 163 & 131 \\
2. Red clover (R+A) & 0.090 & 0.115 & 1.63 & 1.88 & 207 & 200 & 148 & 164 \\
3. White clover (R) & 0.090 & 0.120 & 1.59 & 1.80 & 194 & 196 & 163 & 135 \\
4. White clover (R+A) & 0.080 & 0.105 & 1.55 & 1.76 & 170 & 185 & 154 & 168 \\
5. Timothy (R) & 0.095 & 0.120 & 1.64 & 1.78 & 161 & 163 & 174 & 130 \\
\hline
\end{tabular}

Note: 1 - before trial establishment, 2 - after ploughing in of perennial grasses

During mineralization of nitrogen-rich residues of legumes, the gradually released nitrogen has a positive effect on the formation of yield biological parameters during all cereal growth stages, unlike mineral fertilisers of which a large part is leached (McGuire et al., 1999). The productivity of cereals is determined by a lot of characteristics and traits: growing period, overwinter survival, ear productivity, grain size, photosynthetic efficiency, disease resistance and others (Chlebnikov et al., 1997; Plyčevaitienè, 2002).

\section{Yield forming indicators, grain yield and grain protein content}

Crop stand density data show that triticale had a significantly higher number of plants, which made up by $11.0 \%$ more compared with rye (Fig. 1 ).

Preceding crops did not have any effect on crop stand density. Similar data were obtained while analysing biological value of legumes in agrocenoses on heavy loam soils (Arlauskienè et al., 2001). Insignificant differences in the number of plants per area unit might have occurred due to different seed placement depth, different seed vigour and other factors. The most important factor for high yield is the number of productive stems per area unit. It shows biological stability of the variety, its persistence or resistance to variable environmental conditions (Chlebnikov et al., 1997; Plyčevaitienè, 2002).

The intensity of productive tillering of all crops was also dependent on the weather conditions. In 2004, when there was a shortage of moisture during the growing season, i.e. the rainfall constituted only $72 \%$ of the long-term rate, the mean tillering coefficient of triticale was 1.17 , and of rye 1.08 . In 2005 when during the growing season the amount of rainfall was $169 \%$ of the long-term rate, the mean tillering coefficient of triticale was lower (1.08), and of rye higher (1.13). Cereal species had a significant effect on the formation of productive stems. The number of productive stems in triticale crops was on average 322.6 per $\mathrm{m}^{2}$ or by $21.8 \%$ more than that of rye. The highest number of productive stems formed in the cultivation sites where red clover aftermath had been ploughed in. 
Number of plants $\mathrm{m}^{-2}$

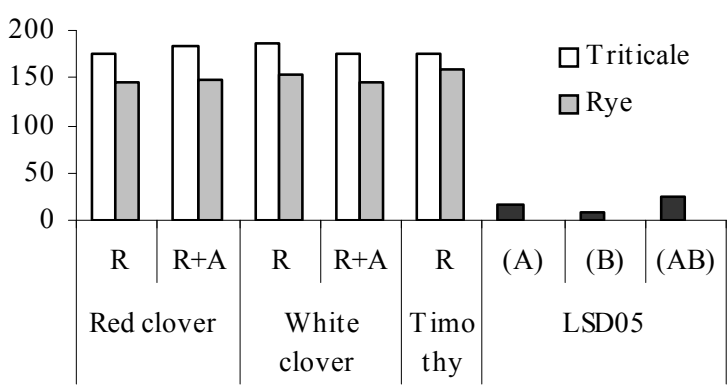

Plant height $\mathrm{cm}$

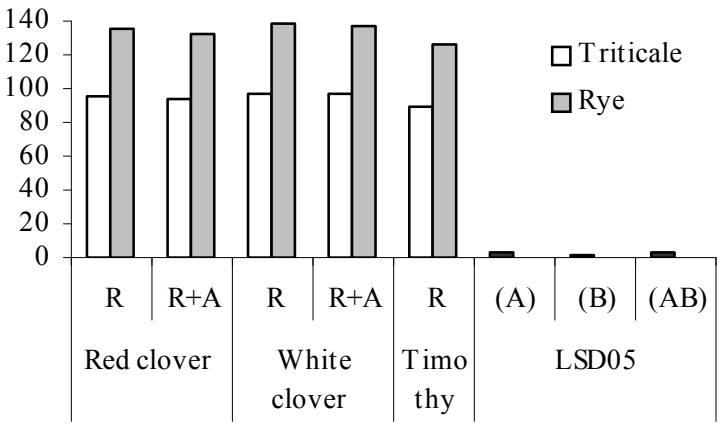

Number of grain per ear

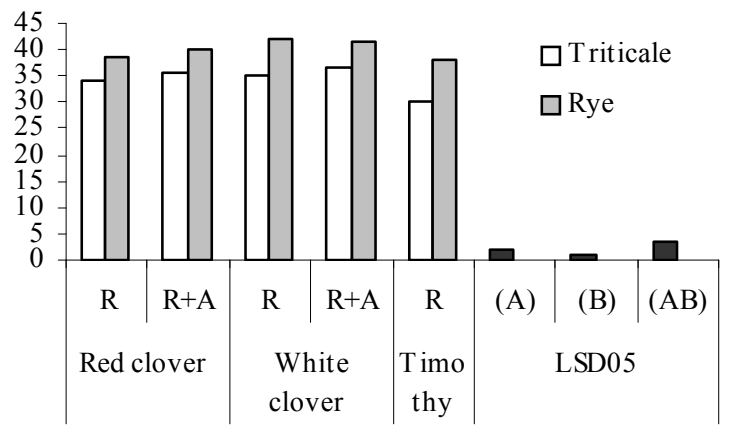

Productive stems $\mathrm{m}^{-2}$

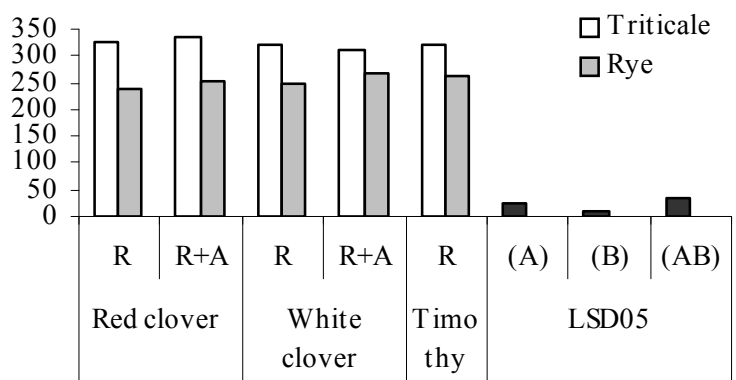

Ear length $\mathrm{cm}$

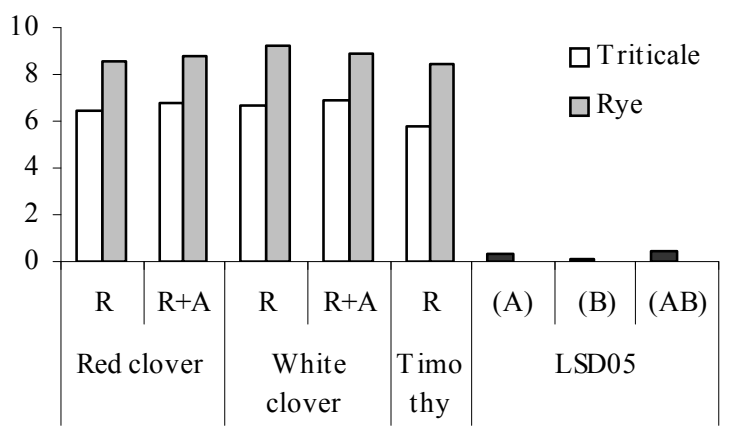

1000 grain weight $\mathrm{g}$

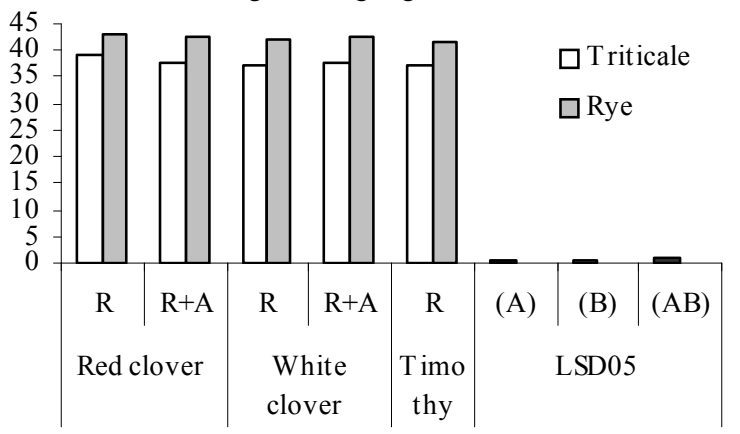

Figure 1: The effect of preceding crops on the triticale and rye yield forming indicators

Plant height is a very variable trait that depends on the characteristics of a variety, weather conditions and geographical terrain (Plyčevaitienè, 2002). Diverse nitrogen contents in clover residues and aftermath determined different plant height of cereals. The greatest plant height of both cereal species was recorded in the treatments fertilised with white clover. Having compared white clover treatments no significant differences were revealed, but different management of red clover did have some significant effect. Having ploughed in red clover residues cereals grew taller. Cereals grown after timothy were the shortest.

Similar data were obtained while analysing ear length. The ears of cereals grown after timothy were significantly shorter $(8-10 \%)$, compared with clover preceding crops. Different clover green manures did not have any significant effect on ear length; inappreciably longer eras were recorded only after white clover.

Averaged data show that winter rye matured $17.5 \%$ more grain (or 6 grains more) per ear compared with winter triticale. The higher number of grain per era for the varieties of both cereals was obtained in the treatments fertilised with white clover residues and aftermath.

1000 grain weight varies due to different weather conditions during grain formation and ripening stage and is affected by fertilisation and number of plants per 
area unit (Plyčevaitienè, 2002). 1000 grain weight of winter rye was significantly higher $(4.6 \mathrm{~g})$ than that of triticale. 1000 grain weight was less affected by preceding crops than the number of grain per ear. The lowest 1000 grain weight was recorded after timothy and white clover of which only residues were ploughed in. However, having incorporated a larger amount of green manure, i.e. red clover residues and aftermath and white clover aftermath the soil received more nutrients. This leads to the conclusion that a higher content of biological nitrogen incorporated had a significant effect on 1000 grain weight of cereals.

Grain yield $t$ ha $^{-1}$

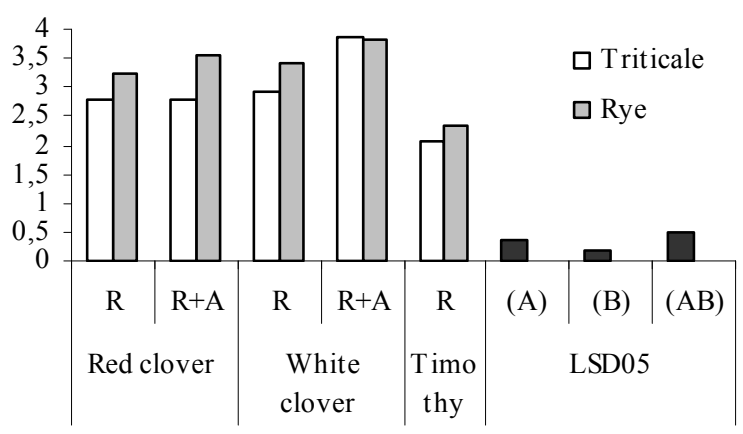

Cereal species had the greatest effect on both 1000 grain weight and grain yield, the effect of the preceding crop was lower. Averaged data show that rye grain yield, irrespective of different preceding crops, was by $0.38 \mathrm{t}$ $\mathrm{ha}^{-1}$ higher than that of triticale. Comparison of the preceding crops indicates that having ploughed in white clover aftermath the highest cereal grain yield was obtained. Ploughing in of white clover aftermath increased triticale grain yield by $0.94 \mathrm{t} \mathrm{ha}^{-1}$ and that of rye by $0.41 \mathrm{t} \mathrm{ha}^{-1}$, whereas ploughing in of red clover aftermath exerted some effect only on rye grain yield (Fig. 2).

\section{Figure 2: The effect of preceding crops on triticale and rye grain yield and grain protein content}

Different enrichment of soil with nutrients did not have any significant effect on protein content in cereal grain (Fig. 2). In all cases nitrogen content in triticale grain was by $5-35 \%$ higher than that of rye. Only in rye grain nitrogen content was positively influenced by nitrogen-rich plant residues. Comparison of the preceding crops shows that the highest nitrogen increase $(18 \%)$ was obtained having ploughed in aftermath of white clover.

Table 4. Results of Fisher-test of productivity parameters
Different preceding crops and diverse amounts of nutrients contributed to the soil determined different formation of yield biological parameters of winter rye and triticale. Analysis of variance of the data suggests that crop stand density and the number of productive stems were significantly affected only by the species of cereals $\left(\mathrm{F}_{\text {fact. }}=19.49>\mathrm{F}_{\text {theor. } 0.1}=7.06\right.$ and $\mathrm{F}_{\text {fact. }}=32.82$ $>\mathrm{F}_{\text {theor.0.1 }}=7.06$ ), and plant height, ear length, number of grain per ear, 1000 grain weight and grain yield were affected by both factors investigated, i.e. by preceding crops of winter cereals and cereal species (Table 4).

\begin{tabular}{lcccc}
\hline \multirow{2}{*}{ Productivity parameters } & \multicolumn{3}{c}{ Variance } \\
\cline { 2 - 5 } & Treatment & Factor A & Factor B & Interaction AB \\
\hline Number of emerged plants & 1.66 & 0.21 & $13.49^{* *}$ & 0.16 \\
Number of productive stems & $3.92^{* *}$ & 0.12 & $32.82^{* *}$ & 0.50 \\
Plant height & $129.98^{* *}$ & $9.67^{* *}$ & $1129.22^{* *}$ & 0.48 \\
Ear length & $23.98^{* *}$ & $3.86^{* *}$ & $197.17^{* *}$ & 0.80 \\
Number of grain per ear & $4.72^{* *}$ & $2.87^{*}$ & $29.65^{* *}$ & 0.34 \\
1000 grain weight masė & $29.82^{* *}$ & $3.1^{*}$ & $252.71^{* *}$ & 0.81 \\
Grain yield & $5.02^{* *}$ & $9.46^{* *}$ & $4.89^{* *}$ & 0.61 \\
\hline
\end{tabular}

Similar regularities of green manure effect were identified while comparing lucerne, red clover and vetch-oats mixture on heavy-textured soils (Arlauskienè et al., 2002; Janušienè et al., 2004; Makštėniené et al., 2001). The efficiency of green manure in sandy loam soil increases when using this management means 
together with mineral fertilisation (Romanovskaja et al., 2003; Vaišvila et al., 1997).

\section{Diseases incidence and severity}

Grain yield in cereals depends not only on such yield components: number of ears per unit area, number of grains per ear, grain weight per ear and 1000 grain weight, but also on plant resistance to diseases. A strong mutual compensation is usually found between all productivity components and plant resistance to disease. However, a limitation of one component can not be completely compensated for by the others. Grain weight predominantly depends on how much the plant assimilates during the stage of grain-filling, and this is closely related to the area of long-lived green leaves. The favourable results of effective disease control on grain yield are largely based on a higher long-lived green leaves (Darwinkel, 1978).

The spread of the following foliar diseases during the experimental period was more intensive: in rye - scald and brown rust, in winter triticale - scald, brown rust and septoriosis. Experimental findings suggest that in 2004 scald affected from 29.2 to $47.5 \%$ of rye leaves and severity of this disease was from 7.0 to $9.75 \%$. In
2005 scald was extremely severe and affected from 50.8 to $69.2 \%$ of rye leaves, severity was from 8.75 to $18.32 \%$. Significant differences were determined between treatments, i.e. the incidence of scald in rye grown after variously-managed preceding crops was different.. According to the average research data, rye that grew after white clover whose aftermath was ploughed in $(\mathrm{R}+\mathrm{A})$ was by 1.4 times more affected by this disease causal agent and rye that grew after white clover whose only residues were ploughed in $(\mathrm{R})$ was affected by 1.3 times more compared with the rye preceded by timothy (Fig. 3). The severity of scald was also higher in rye grown after white clover by 1.1 and 1.2 times, respectively. Rye stand density (different number of productive stems) did not have any effect on scald severity and incidence $(r=0.171$ and 0.215$)$ in 2004. But the lowest incidence of this disease was recorded in rye grown after variously managed red clover in 2005. The incidence and severity of scald depended also on rye stand density. A medium strong positive correlation was identified between scald incidence and severity and the number of rye productive stems: incidence: $\mathrm{y}=21.976+0.132 \mathrm{x}, \mathrm{r}=0.638 * *(\mathrm{P}<$ $0.05)$; severity: $\mathrm{y}=0.097+0.062 \mathrm{x}, \mathrm{r}=0.598 * *(\mathrm{P}<$ $0.05)$.

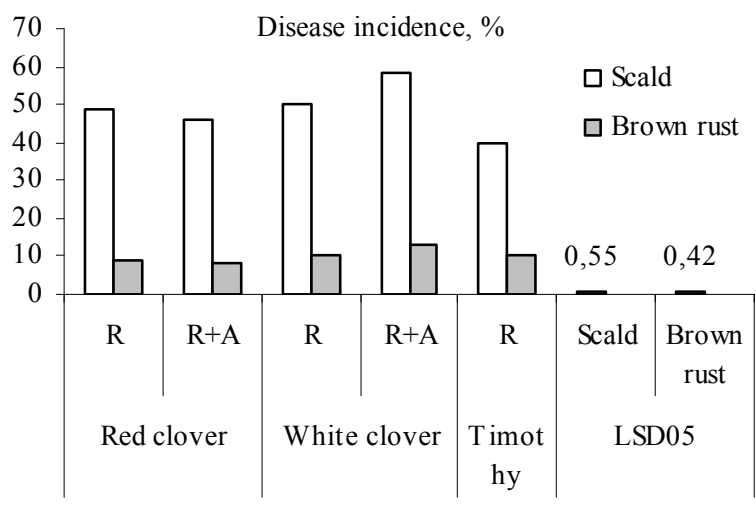

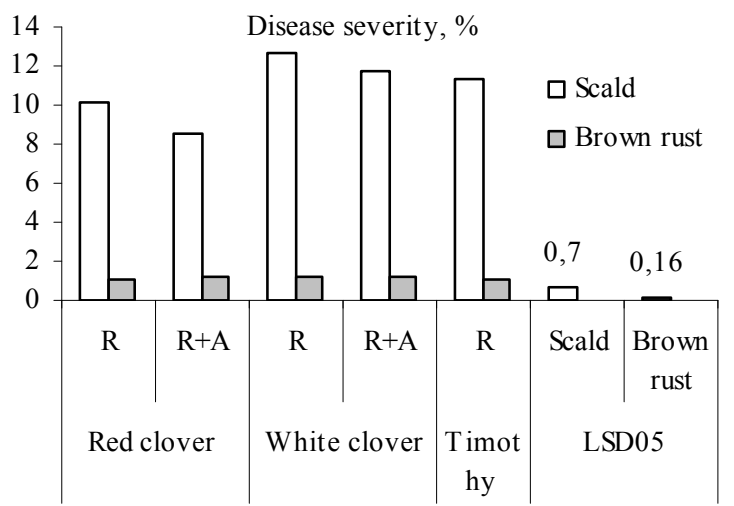

Figure 3: The effect of preceding crops on rye foliar fungal diseases incidence and severity. Average data of $2004-$ 2005.

In 2004 and 2005 the incidence of brown rust in rye agrocenose was similar, however, the disease severity was different. In 2004 the higher amount of rainfall in June promoted a more intensive occurrence of brown rust in rye, whereas warmer and drier weather during the same period in 2005 resulted in $2.2-3.0$ times lower severity of the disease. So, incidence of brown rust was from 5.8 to $16.6 \%$ in 2004 and from 9.2 to $12.5 \%$ in 2005 , and severity - from 1.51 to 1.83 and from 0.52 to 0.85 respectively. The greatest number of brown rust-affected rye $(10.8-16.6 \%)$ in 2004 was identified in the treatments where rye was grown after variously-managed white clover, and the rye preceded by red clover and timothy were the least-affected. In
2005 , conversely, the rye grown after red clover and timothy was by 1.1-1.4 times more affected by brown rust, compared with the rye grown after white clover. Average research data suggests that rye growing in different conditions, i.e. after different preceding crops does not have any consistent effect on brown rust incidence and severity (Fig. 3). However, a medium strong correlation was identified between rye stand density and brown rust incidence in 2005: $\mathrm{y}=16.047-$ $0.019 \mathrm{x}, \mathrm{r}=-0.606^{* *}(\mathrm{P}<0.05)$.

In the experimental years the incidence of scald was rather high not only on rye but also on winter triticale. In 2004 after different preceding crops from 31.3 to 
$52.5 \%$ of winter triticale plants were scald affected and in 2005 from 18.8 to $21.3 \%$. According to the average research data significant differences in the incidence of scald were determined between all treatments, however the highest incidence and severity of scald were identified in winter triticale grown after legumes (red and white clovers), compared with the triticale preceded by spiked plants (Fig. 4). Winter triticale stand density had a great effect on the incidence of scald, there was identified a correlation between scald incidence and the total number of winter triticale stems $(\mathrm{y}=38.085-$ $\left.0.049, \mathrm{r}=-0.565^{*} ; \mathrm{P}<0.05\right)$ and between scald incidence and the number of triticale productive stems $\left(\mathrm{y}=37.179-0.056 \mathrm{x}, \mathrm{r}=-0.778^{* *} ; \mathrm{P}<0.05\right)$. Different triticale stand densities did not have any effect on the severity of scald $\left(r=-0.267^{*}\right.$ and $-0.166^{*}$, respectively).

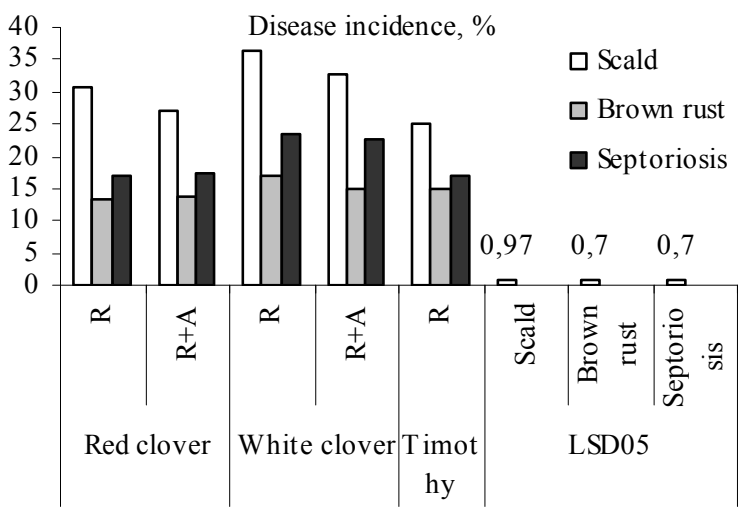

During the experimental period in all agrocenose winter triticale was affected by brown rust causal agent Puccinia recondita Roberge ex Desmaz., however the disease severity was very low and in most cases did not reach $1 \%$. In some cases only the traces of the disease were identified. The relationship between the incidence of brown rust and ecological conditions of cereal cultivation site was identified: in 2004 by $5.0-7.5$ percentage units higher disease incidence was recorded in winter triticale which was preceded by variouslymanaged white clover. However in 2005 an opposite trend of brown rust incidence was observed, the disease incidence was by $1.4-1.6$ times higher in the cultivation sites where timothy residues were ploughed in for the preceding crop of the cereal, compared with winter triticale grown after white clover.

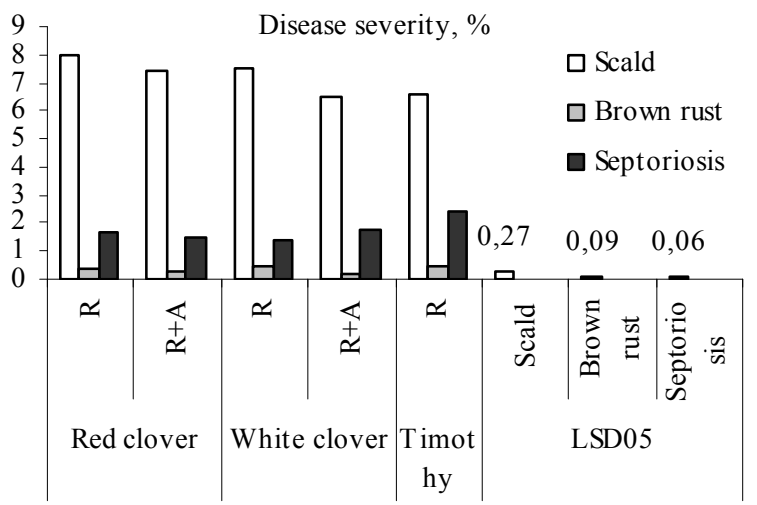

Figure 4. The effect of preceding crops on triticale foliar diseases incidence and severity. Average data of 2004 2005.

Moderately strong infection of septoriosis was identified in winter triticale (Fig. 4). The incidence of septoriosis, and in many cases severity, was significantly affected by different winter triticale growing conditions, especially in 2004 the infection level on winter triticale grown after differently-managed white clover was twice as high as in triticale preceded by timothy. As the average data show, the highest disease pressure was identified in triticale grown after white clover whose residues $(\mathrm{R})$ and aftermath were ploughed in $(\mathrm{R}+\mathrm{A})$ : the triticale grown under such conditions were septoriosis affected by $1.4-1.6$ times more than triticale grown after the other preceding crops (Fig. 4).
Slightly fewer leaf spot-affected winter triticale leaves were identified in the stands with a lower plant density $r$ $=-0.395^{*}$.

Disease resistance are very highly dependent on the weather conditions of the year of cultivation and genotype. It is noteworthy that winter rye varieties are characterized by yield stability between years, whereas triticale productivity varies more markedly. When weather contitions are unfavorable or, when there is a shortage of nutrients, the varieties are incapable of actualizing their genetic potential and resistance to diseases too (Sliesaravicius et al., 2006).

\section{CONCLUSIONS}

Various preceding crops largely determined chemical properties of light loamy soils. The highest humus contents accumulated in the soil after red clover aftermath, while the highest contents of nitrogen, phosphorus and potassium accumulated after white clover aftermath.

Nitrogen and potassium-rich red clover aftermaths used as green manure increased the number of productive

Acta agriculturae Slovenica, 93 - 2, julij 2009 
stems and 1000 grain weight. Variously -used white clover preceding crop had a positive effect on plant height, ear length and grain number per ear.

Ploughing in of white clover aftermath increased triticale grain yield by $0.94 \mathrm{t} \mathrm{ha}^{-1}$ and that of rye by 0.41 $\mathrm{t}$ ha-1, whereas ploughing in of red clover aftermath exerted some effect only on rye grain yield.
Host-plants growing conditions influenced the incidence of some diseases. In winter triticale preceded by white clover we identified a more intensive occurrence of diseases, such as septoriosis, compared with other preceding crops. It was identified a more intensive occurrence of diseases, such as scald in rye preceded by white clover compared with the other preceding crops too.

\section{REFERENCES}

Alaru M., Laur Ü., Jaama E. 2003. Influence of nitrogen and weather comditions on the grain quality of winter triticale. Agron. Research 1: 3-10.

Arlauskienè A. 2000. Ankštinių žolių, kaip priešsèlių, bei jų žaliosios masès užarimo trąšai įtaka dirvožemio savybėms ir javų grandies produktyvumo formavimuisi. Žemdirbystė 70: 4865 .

Arlauskienė A., Maikštėnienė S. 2001. Ankštinių augalų biologinè vertè agrocenozėse. Žemès ūkio mokslai 1: $22-30$

Bailey K.L., Duczek L.J. 1996. Managing cereal diseases under reduced tillage. Canadian J. of Plant Path. 18: 159-167.

Conway K.E. 1996. An overview of the influence of sustainable agricultural systems on plant diseases. Crop Protection 15: 223-228.

Darwinkel A. 1978. Patterns of tillering and grain production of winter wheat at a wide range of plant densities. Neth. J. Agricultural Science 26: 383-398.

EPPO Standarts. 1997. Guidelines for the efficacy evaluation of plant protection products. Fungicide 2: 5-105.

Eyal Z. 1999. Septoria and Stagonospora diseases of cereal: a comparative perspective. Proceedings of the $15^{\text {th }}$ Long Ashton International Symposium Understanding Pathosystems: a Focus of Septoria, $1-25$.

Gaurilčikienè I., Lisova R. 1999. Grybinių ligu paplitimas skirtingai tręštuose tetraploidiniuose rugiuose. Žemdirbystès instituto užbaigtų tiriamuju darbų konferencijos pranešimai 31: 22-25.

Granstedt A. 2000. Ecological grassland management in the Nordic Countries. In: proceedings of the International Symposium: Conventional and ecological grassland management, Tartu., 45-62.

Hutcheon J.A., Jordan V.W.L. 1996. Influence of cultural practice and rotation on the incidence of stem-base disease in systems comparisons 19891994. Aspects of Applied Biology 47: 343-350.

Lisova R., Greimas G., Tripolskaja L. 1996. Tręšimo sistemu itaka grybinių ligų išplitimui javuose, esant skirtingai sejomainai ir priešsèliams. Žemdirbyste 52 : $72-87$.

Loivẽke H., Laitamm H., Sarand R.J. 2003. Fusarium fungi as potential toxicants on cereal and grain feed grown in Estonia during 1973-2001. Agron. Research 1-2: 185-196.

Janušienė V. 1992. Biologinė medžiagų apykaita natūraliose ir kultūrinèse biogeocenozėse. Dirvotyra 40: $98-108$.

Janušienė V., Žekonienė V. 2004. Žaliosios trąšos poveikis humuso bei mineralinio azoto pokyčiams priesmèlio dirvožemyje. Žemès ūkio mokslai 4: 1-6.

Magyla A., Šateikienė D., Šlepetienè A. 1997. Augalinių liekanų kiekis, jų cheminè sudètis ir dirvožemio humusas įvairios specializacijos sėjomainose. Žemdirbystė 58: 56-75.

Magyla A., Endriukaitis A., Žemaitis V., Kaunas J., Simanavičienė O., Rainys K., Jovaišienè E., Vizgirda M. 2001. Svarbesnių pasėlių išsidèstymas Lietuvoje ir jų koncentracijos arealai. Akademija, 65 p.

Magyla A., Svirskienė A., Šlepetienè A. 2004. Dirvožemio agronominių savybių pokyčiai auginant žirnius po skirtingu priešsėlių ir stebint ju poveiki žieminiams kviečiams. Žemdirbystė 85: 102-119.

Maikštėnienė S., Arlauskienė A. 2001. Ankštinių augalų reikšmė agrosistemos produktyvumo didinimui sunkaus priemolio dirvožemyje. Ekologija 1: 23-30.

McGuire A.M., Byrant D.C., Denison R.F. 1999. Wheat yields, nitrogen uptake, and soil moisture followingwinter legume cover crop vs. fallow. Agron. J. 90: 404-410.

Plyčevaitienė V. 2002. Žieminių rugių linija LŽI 347. Žemdirbystė 77: 162-169. 
Romanovskaja D., Tripolskaja L. 2003. Ivairių organinių trąšu naudojimo priesmèlio dirvožemyje agroekologinis įvertinimas. Žemdirbystė 84: 3-22.

Sliesaravicius A., Pekarskas J., Rutkoviene V., Baranauskis K. 2006. Grain yield and disease resistance of winter cereal varieties and application of biological agent in organic agriculture. Agron. Research, 4: 371-378.

Šurkus J., Gaurilčikienè I. 2002. Žemès ūkio augalų kenkèjai, ligos ir jų apskaita. Akademija, 345 p.

Tarakanovas P., Raudonius S. 2003. Agronominių tyrimų duomenų statistine analize taikant kompiuterines programas ANOVA, STAT, SPLITPLOT iš paketo SELEKCIJA ir IRRISTAT. Akademija, 55 p.
Vaišvila Z., Mažvila J., Ryliškienè E., Arbačiauskas J. 1997. Mineralinių trąšu itaka žemès ūkio augalų derliui, jo kokybei, maisto medžiagų balansui ir ekologinei būklei vidutinio sunkumo limnoglacialiniame priemolio dirvožemyje. Žemdirbystė 60: 24-37.

Трепащев Е.П. 1979. О понятий вынос азота для бобовых культур. Агрохимия 11: 21-23.

Хлебников Н.Г., Макаров В.И., Маслова Н.Ф. 1997. Сравнительная оценка сортов озимой ржию. Зерновые културы 3: 13-14.

Шпаков А.С. 1999. Роль полевых и естественных кормовых растений в агроландшафтах. Кормопроизводство 12: 12-17. 